\title{
War Veteran as Victim and Victimizer in Bill Cain's 9 Circles
}

\author{
Majeed Ismail Fayadh \\ Assistant Professor, Dept. Of English, College of Arts, University of Anbar, Iraq
}

\begin{abstract}
Bill Cain's 9 Circles is a play about a war veteran who is deluded by the American capitalists and sent to Iraq. Though he does not conform to the standard requirements of recruitment, yet he is recruited and sent to the battlefield. He is misled by the propaganda of war that he is going to fight an enemy. Once he is in Iraq, one of his colleagues is killed and hanged for some days, he becomes preoccupied with revenge. He commits a heinous crime raping a young girl, murdering her and her family. This paper shows how does the American elite manipulate everything for their interests. They falsify truth and create false consciousness in the minds of Americans terrifying them of the threat of Iraq. The paper also reveals the hypocrisy of the elite and how they try to find a scapegoat for any crime that is leaked to mass media.
\end{abstract}

Keywords: false consciousness, victim, victimizer, war veteran

DOI: $10.7176 / J L L L / 67-06$

Publication date: April $30^{\text {th }} 2020$

Bill Cain's 9 Circles takes its structure from the inferno of Dante's Divine Comedy. The play depicts the journey of the soldier Steven Dale Green ( renamed in the play as Daniel Edward Reeves) who is made to pay the ultimate price for the policy of the second Bush administration. Green ( born 1984) served in Iraq and was accused of raping and murdering a 14-year old Iraqi girl, Abeer Qassim Hamza Al- Janabi and murdering her family inside their home in Mahmudiya south Baghdad. He then set fire to the house before leaving with his 4 accomplices. Green was charged and sentenced to life sentence and found dead in his cell in 2014. (Wikipedia, Steven Dale Green).

The play has been subject to a lot of debate and analysis. Most of the literary criticism the play received, has concentrated on the life of this veteran as a journey of sin and redemption. The writer John Coleman states how the production of the play makes him think of many controversial topics, mainly politically- motivated torture practices, post-traumatic stress Syndrome and suicide rates. He speaks of his reaction to the final soliloquy of Reeves, saying," I, for one, would have found it hard to sentence him to death."(2010) this shows his sympathetic response to the plight of this veteran.

Alexandra Bonifield ( A critic for criticalrant.com) comments that the audience peers into the heart, mind and soul of the soldier and looks at him as a military system pawn as a scapegoat as well as an agent of evil (2011).

The reviewer Lucy Griffin differentiates between reading the story of Green's vicious crime and watching the production of the play at the Los Angeles Bootleg Theater. She states that the audience is able to realize that the soldier has become a scapegoat, a tool being used to prove a point on morality in a war completely devoid of moral. This soldier has been abandoned by his army brothers who are confessing to his crime to avoid their own. Griffin goes further to say that the play offers one of the important lessons that is how to feel the pain of the enemy. (2011).

Sarah Saddler, in her dissertation, " Bill Cain's 9 Circles: Re-evaluating an American Understanding of the Military and Individualism", deals with the play as a traumatic experience addressing the myth of the American soldier in Iraq. Her analysis is to deconstruct the civilian- minded mentality to better understanding war and to question the collective responsibility toward understanding wartime experience. (2013)

This paper explains how the American soldiers become victims of the false consciousness created and implanted in their minds by the dominating class and consequently turn to be victimizers in Iraq. They were recruited and sent to war under the pretext of defending their country against the axis of evil represented by Iraq and threat of the so called MDW ( Mass Destruction Weapons)that allegedly Iraq was trying to develop. Marx and Engels explain how the dominant class falsifies people's consciousness. They believe that the ruling class uses power and money to falsify the truth and to rationalize what is irrational. In other words, the dominant material forces are responsible for the dominant ideology:

The ideas of the ruling class are in every epoch the ruling ideas: i.e, the class, which is the ruling material forces of society is at the same time its ruling intellectual force. $(1970,30)$ 
The state, according to Althusser, can control its citizens through two ways; either repressive or ideological. Repressive state measures depend on violence, that makes use of the government, the army, the courts, the police, and the prisons while the ideological way includes institutions such as church, family, the school, and the media.(Rice, 1989).

Critical sociological theory provides insight into the role of media and other institutions in influencing public opinion. The Frankfurt writers look at oppression in modern society as more deceptive. they also argued that the centre of domination in the modern world has shifted from the economy to technology and culture. While in Exile in the U.S, the members of Frankfort school came to believe that the American " popular culture" was highly ideological and worked to promote the interests of the American capitalism. (Kellner, 2017).

In order to convince the public opinion and make the idea of war as a need to save the country from possible terrorist attacks, the American capitalist elite used cultural institutions ( especially mass media) to create moral panics among the Americans. According To Bonn, The moral panic that should be created involves targeting a particular group or individuals who are socially defined(allegedly) to be responsible for creating a threat to society. He adds that after accusing such a group or individuals as being a threat, they are labeled as folk devils in mass media so those in power seek to eliminate the troublesome group and resolve the moral panic usually by declaring war on that enemy. (Bonn,2010)

The Bush administration used punitive rhetoric, the word "evil" and " folk devils" to define the regime of Saddam Hussein. Such an agenda influences the public opinion through framing the issue of the alleged Iraqi threat. This kind of rhetoric was designated to incite public hostility toward Iraq by building on negative images of Arabs( Muslims) in the minds of Americans.(Bonn,2010)

Paul levy clarifies the real intention behind such an agenda by stating that the private interests that control the government have incredible mind- control propaganda machine at their disposal in the form of the mainstream media, which if not quite fully owned and controlled, is certainly under their" influence" enough to serve their underling self- serving agenda.( 2010 )

For Levy, WMD, which stands for weapons of mass destruction that Iraq was accused of developing, could easily stand for " Weapons of Mind Deception" as the government is continually trying to deceive the "minds" of people which is the battlefield in which the war on consciousness is being fought. He adds that instead of shooting us, the government is using cutting-edge mind- control technology to psychically emasculate us.( 2010$)$.

Chomsky also argues that the elite creates false consciousness to stupefy and pacify the public and this erodes any possibility or even thought of criticism or critique. (1997)

Bill Cain's 9 Circles starts with circle one in Iraq. The scene shows a conversation between a lieutenant and Reeves who is a private army soldier. The lieutenant reads an honorable discharge accusing Reeves of committing a crime. The purpose of the scene is to build up the dramatic tension before conveying the details of the crime. The audience grasps that Reeves is a victim of the propaganda of war and the image he has about the people he is going to deal with:

Reeves: Somethings don't bother me the way they

bother some people, Sir.

Lieutenant: Like?

Reeves : The basics, sir, Killing people. It bothers some

People, Sir.

Lieutenant: It does not bother you?

Reeves: We came here to kill people, Sir.

Lieutenant( gung ho): Soldier, We came here to build up

A nation. That is our mission......

Reeves( even more gung ho): Sir, I don't mean we're here

To kill all the people. Just the ones who

hate freedom. Whoever is left when 
The killing stops- That's the nation.

(Cain, 2011, 256)

It is clear that this soldier as well as others have been taught that they have been sent to fight an enemy though it is revealed that Reeves suffers mental disorder before being recruited and that disorder is one that " can't be fixed" (256). Then Reeves recites the military oath to show he is deeply committed to every word in it:

.... I, Daniel Edward Reeves, do SOLMENLY SWEAR I

will SUPPORT AND DEFEND the constitution of the

United States AGAINST ALL ENEMIES FOREIGN AND

DOMESTIC; that I WILL BEAR TRUE FAITH and allegiance

To the same; and that I WILL OBEY THE ORDERS OF THE

PRESIDENT OF THE UNITED STATES and the orders the

of the officers appointed over me, according to regulations

and THE UNIFORM CODE OF MILITARY JUSTICE. SO-HELP-

ME-GOD. So help me God the first time I said it- ( moved)

I knew it was the truest thing that I ever said. Do not make

Me break my oath. ( 259)

Circle two shows Reeves's past. The audience learns that Reeves has had bad habits like drunk driving. Young Female Lawyer ( YFL) is introduced stating that she believes that people are able to do anything during times of duress. She tells Reeves that he is not her responsibility and he will be handed to a lawyer the following day. She also expresses her disgust at his crime. Actually, with the exception of the Defense, not only this female lawyer, but most of the characters who are going to meet Reeves , represent in one way or another the institutions of the government.

In Circle three, we are introduced to an Army Attorney. He represents the military institution . He considers Reeves to be a stain on the image of the United States. The audience easily grasps the hypocrisy of the elite (Bush Administration). They are never offended by thousands of American soldiers killed in Iraq but they are shocked by Reeves's crime. The Army attorney addresses Reeves, "you scared them" ( 271) and the President himself "went on television and spoke to the nation about you". (268)

The Army Attorney discloses part of the truth when he says, " If this had happened in Midland, Texas, they would have never cared. But it didn't. It happened in the middle of their war and you have scared them." (272). The reality is that even this crime would never scare them if it had not come out to the press media by Al-Jazeera space channel which broadcasted it. The Lawyer states that," .. The story didn't come out for weeks. Then AlJazeera combined the two and created a propaganda bonanza." (290).

The Army attorney informs Reeves that the President describes him as, " a stain on the United States' honorable image." ( 268). He then expresses his astonishment at recruiting a man with, " antisocial personality disorder." ( 274). Reeves has had a bad social record. He has drug convictions, no high school diploma, and no employment record before he comes to Iraq. So why such man is recruited and sent to the battlefield. The Army Attorney states that, " The Army knew what it was getting when it took you.... They had to lower every requirement they have to get you in." (273) adding later that," .. In most states, you wouldn't be allowed to own a gun and yet-" (273).

Fred Kaplan says that the Army is lowering recruitment standards to levels not seen in at least two decades, and the implications are severe- not only for the future of the Army, but also for the direction of U.S foreign policy.( 2008) He adds, " in order to meet recruitment targets, the Army has even had to scour the bottom of the barrel".(2008). he warns the country saying that it is not good to place the burdens of defense so disproportionately on the most downtrodden citizens. (2008). Facts, revealed by the Army Attorney, show that Bush administration pays no attention to the huge causalities both sides suffer but for its own interests.

The interests of the elite requires mobilization of efforts regardless of the standard requirements. That's obvious when Reeves himself expresses the agenda the Army used to recruit him; 
You know what the recruiter said to me? He said, "Son this will be a new start for you." You Know how much I wanted to hear that? I thought fuck- may be they can beat something new into me........ They advised me of my rights. RIGHTS? I didn't want any fucking RIGHTS.( 270)

In Circle four, a Pastor comes to visit Reeves in his cell. Reeves expresses his misery and bewilderment; " You're just the wrong tool for the job. I don't need a pastor. I need a lawyer." ( 277) The Pastor knows well what Reeves has committed, "Son, you raped a girl, led others to do the same, and then you killed her and her whole family."(277). Then he comments on what Reeves needs stating, " ... you broke all Ten of the Lord's Commandments at one crack and broke 'em hard. Son, that Lawyer was the wrong tool for the job. You need Jesus.( A Smile) And I'm going to take you to him." (277). The Pastor then tells Reeves of a story of a girl in the Bible and that girl was possessed by a demon and her mother asked Jesus to drive the demon out. Reeves gets the meaning the Pastor intends to express so he asks the Pastor, " You think I'm possessed, Pastor?" ( 279). The Pastor, representative of the church, is another agent of the government. His role does not exceed the idea of purification of the sinful soul of Reeves. He does not come to save Reeves or find a way to save him from his ultimate fate.

Circle five introduces a civilian lawyer who is enthusiastic and likeable. He shows a keen insight into the minds of criminals like Reeves for he has a good experience dealing with murders and rapists. Like others, he declares that he has come to help Reeves. Reeves shows unwillingness to deal with him telling him , "Sir, I was warned about you. You'll turn everything upside down. You're a lawyer, Sir." (285). When the Lawyer learns the identity of the warner to be a preacher, He states that, " Preachers usually turn things upside down." ( 285). At this moment Reeves reacts violently expressing his opinion of those who come to visit him;

Don't play with me, Sir. People always play with me. They say they'll come back and they don't. They say, " say 'not guilty," then they throw me in jail. They swear me in and they throw me out. I think it's driving me insane, SIR. (285).

In Circle Six, the audience comes to know Reeves as a soldier who has lost a beloved lieutenant. This scene shows the real motives behind Reeves's crime. The Shrink's role is to comfort Reeves in his trauma.

Circle Seven introduces the Prosecution who is shown as very strong. She is pre-occupied with one thing, that is justice for the child and her family. The dialogue between the Prosecution and the Defense reveals the real workings of the elite's machine that runs the war. When the Defense states that, "the crime we are discussing only ended in Iraq. (Then) It began in a recruiting office in Texas." ( 306) He tries to put the blame on the recruiting office for it," met a deeply troubled nineteen- year- old with convictions for alcohol, drug abuse, violence." (306) The Prosecution refuses to make the war on trial, "The war is not on trial here. A man accused of a specific crime is." (306) The Defense and the Prosecution hold on their opinions related to the responsibility of such crimes. When the defense expresses his surprise at such "strange trial in which there is absolutely no evidence." ( 306), The prosecution declares that, " there is testimony: (306). Here the Defense attacks such testimony in which," Every bit of it coming from men and women who outrank my client placing every bit of the blame on him- the lowest ranking man involved in this incident." (306-307). The Defense calls this a ritual that is similar to ancient rituals that were held in the East not far from the scene of this crime. He clarifies that, for terrible crimes in ancient times, all the blame was placed on an animal and that animal was driven into wilderness to die.( 307) He then concludes that, " our government- from the president on down- is calling for the scapegoating of a young man- the lowest ranking man involved in this admittedly horrifying event." (307) When the Prosecution tells the Defense that the testimony shows that Reeves tells his master that, " he was out to kill. To murder. "( 307), The Defense tells him that before that Reeves went to an army psychiatric asking him for help and he was given unrecorded medication and was told to sleep that night but he was recycled the next day to patrol in the area known as the Triangle of Death. (307)

The defense once again insists on discussing the war itself while the Prosecution again insists on investigating this specific crime and refuses to portray Reeves as, " an animal" or " a goat" but as a " man" and " a smart young man." ( 308$)$

The confrontation between the Defense and the Prosecution reaches a closed end for the Defense confirms the cause behind all crimes, " If we had not been there, it would not have happened." (308). In Circle Eight, Reeves stands in front of the audience saying that he has learnt an experience and that no one can keep a secret. He confesses that he raped the girl and killed her and her family showing his deep regret. In the last Circle entitled " Inferno", Reeves remembers those moments of rape and how he still lives them, how he could still see her tears, how she begs him not to kill her. He states that her words still ring in his mind, " Ana Ayaz A'sh" (314) which mean Let me live before he silences her and then a breath comes out of a spirit into the darkness. (315)

This paper shows how a disturbed young man was recruited to serve the private interests of the American 
elite and became a victim to their propaganda of war. He turned to be a tool for their wicked intention to occupy Iraq. He had been taught to fight an enemy and that it was an opportunity for him to prove his loyalty to his country. During his service, he turned to be a criminal and committed a heinous crime with the help of his other colleagues and for that he should pay the price for it as well as others.

\section{Reference}

Bonifield, Alexandra. " Ripples from Hell: " 9 Circles" in Boston \&Dallas." Criticalrant.com. N.P.,June5 2011. Web 10 Sept 2016. Http://criticalrant.com/2011/06/05ripples-from-hell-9-ciecles-in-boston-dallas.

Bonn, Scott .A Mass Deception and the US war on Iraq. New Jersey, 2010. P.21

Cain, Bill. "9 Circles" in Acts of War: Iraq And Afghanistan In Seven Plays. Karen Malpede and Others, Eds. Illinois: Northwestern University Press, 2011. Pp, 253-315

Chomsky, Noam.(1997). Media Control: the Spectacular Achievements of Propaganda. New York: Seven Stories Press

Coleman, John. "9 Circles." America Magazine. 09 Nov 2010: n. p., Web 17 June 2017. Http:/www.americamagazine.org/blog/entry.cfm?entry-id+3526

Griffin, Lucy. " A Descent into Hell: 9 Circles at Bootleg. " LA ARTS BEAT: n. p. , 24 Oct 2011. Web 20 June 2017.< http://www.artsbeatla.com/2011/10/9 Circles/>.

Kaplan, Fred .Dumb and Dumber: The U.S. Army Lowers Recruitment Standards- again. Slate.com Jan 24, 2008.

Kellner , Douglas. "The Frankfurt school and British cultural studies: The Missed Articulation." (http://www.gseis.ucla.edu/faculty/kellner/kellner.html) web 13July20017.

Levy, Paul.(2010) The War on Consciousness. http;//www.awakeninthedream. com/the-war-on-consciousness. Web 27 June 2017.

Marx, Karl., and Frederick Engels. The German Ideology. London: Lawrence and Wishart 1970.

Rice, Philip and Patricia.eds., Modern Literary Theory: A Reader. London: Richard Clay- Bungay, Stuffolk,1989, p. 56.

Saddler, Sarah Louise. " Bill Cain's 9 Circles: Dramaturgically Re- Evaluating An American Understanding of the Military And Individualism." A Ph. D Dissertation. Miami University, Ohio.2013. Http://etd.ohiolink.edu.26 Oct2010. Web 25June2017.

(Wikipedia, Steven Dale Green).Web 21May2017 